\title{
HLA-A*0207 Positive Cells Present
}

National Cancer Institute

\section{Source}

National Cancer Institute. HLA-A*0207 Positive Cells Present. NCI Thesaurus. Code C142818.

An indication that cells expressing HLA-A*0207 have been detected in a sample. 